\title{
Occurrence of whale barnacles in Nerja Cave (Málaga, southern Spain): Indirect evidence of whale consumption by humans in the Upper Magdalenian
}

\author{
Esteban Álvarez-Fernández ${ }^{\mathrm{a}, *}$, René-Pierre Carriol ${ }^{\mathrm{b}}$, Jesús F. Jordác ${ }^{\mathrm{c}}$, J. Emili Aura ${ }^{\mathrm{d}}$, Bárbara Avezuela ${ }^{\mathrm{c}}$, \\ Ernestina Badal ${ }^{\mathrm{d}}$, Yolanda Carrión ${ }^{\mathrm{d}}$, Javier García-Guinea ${ }^{\mathrm{e}}$, Adolfo Maestro ${ }^{\mathrm{f}}$, Juan V. Morales ${ }^{\mathrm{d}}$, \\ Guillém Perez $^{\mathrm{g}}$, Manuel Perez-Ripoll ${ }^{\mathrm{d}}$, María J. Rodrigo ${ }^{\mathrm{d}}$, James E. Scarff ${ }^{\mathrm{h}}$, M. Paz Villalba ${ }^{\mathrm{i}}$, Rachel Wood $^{\mathrm{j}}$

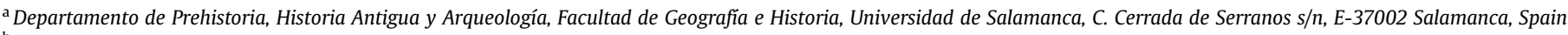 \\ ${ }^{\mathrm{b}}$ Muséum National d'Histoire Naturelle, Département Histoire de la Terre, Case Postale 38, 57 rue Cuvier, F-75231 Paris Cedex 05, France \\ c Laboratorio de Estudios Paleolíticos, Dpto. de Prehistoria y Arqueología, Facultad de Geografía e Historia, Universidad Nacional de Educación a Distancia, \\ Paseo Senda del Rey 7, E-28040 Madrid, Spain \\ d Departament de Prehistòria i Arqueologia, Universitat de València, Avda. Blasco Ibañez 28, E-46010 València, Spain \\ e Museo Nacional de Ciencias Naturales, Consejo Superior de Investigaciones Científicas, C. José Gutiérrez Abascal 2, E-28060 Madrid, Spain \\ ${ }^{\mathrm{f}}$ Departamento de Investigación y Prospectiva Geocientífica, Instituto Geológico y Minero de España, Calle Calera 1, E-28760 Tres Cantos-Madrid, Spain \\ ${ }^{g}$ GI Bioarqueología, IH, CCHS, CSIC, Madrid, Spain \\ h 1807 M.L. King Jr. Way, \#D, Berkeley, CA 94709, USA

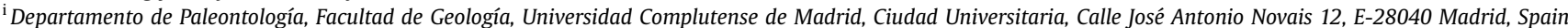 \\ ${ }^{\mathrm{j}}$ Research School of Earth Sciences, The Australian National University, 1 Mills Road, Canberra ACT 0200, Australia
}

\section{A R T I C L E I N F O}

\section{Article history:}

Available online $\mathrm{xxx}$

\begin{abstract}
A B S T R A C T
A total of 167 plates of two whale barnacle species (Tubicinella major Lamarck, 1802 and Cetopirus complanatus Mörch, 1853) have been found in the Upper Magdalenian layers of Nerja Cave, Mina Chamber (Maro, Málaga, southern Spain). This is the first occurrence of these species in a prehistoric site. Both species are specific to the southern right whale Eubalena australis, today endemic in the Southern Hemisphere. Because of Antarctic sea-ice expansion during the Last Glacial Period, these whales could have migrated to the Northern Hemisphere, and reached southern Spain. Whale barnacles indicate that maritime-oriented forager human groups found stranded whales on the coast and, because of the size and weight of the large bones, transported only certain pieces (skin, blubber and meat) to the caves where they were consumed.
\end{abstract}

(c) 2013 Elsevier Ltd and INQUA. All rights reserved.

\section{Introduction}

The earliest information about the consumption of marine resources in Prehistory comes from the oldest layers in PP13B (South Africa), dated to $\sim 164 \mathrm{ka}$ and associated with modern humans (Marean et al., 2007; Marean, 2010). From this period, the archaeological evidence of mollusc shells, crab claws, fish, birds and seals bones have been documented in different parts of the world. They are interpreted as direct evidence for marine animal consumption (e.g. Erlandson, 2001; Jerardino, 2010; Álvarez-Fernández, 2011; Colonese et al., 2011; Steele and Álvarez-Fernández, 2011).

The presence of whale barnacles (Coronula sp.) has been documented in different South African archaeological sites with lithic

\footnotetext{
* Corresponding author.

E-mail addresses: epanik@usal.es (E. Álvarez-Fernández),Emilio.aura@uv.es (J.E. Aura).
}

industries belonging to the Middle Stone Age, e.g. PP13B and Ysterfontein 1 (Avery et al., 2008; Jerardino and Marean, 2010) and Late Stone Age, e.g. Eland's Bay Cave, Dune Field Midden and the Geelbek Dunes (Jerardino and Parkington, 1993; Kandel and Conard, 2003). In contrast, only one whale barnacle fragment (a rostrum of Coronula diadema) from the Upper Magdalenian layers (ca. 13,500 BP) of Las Caldas Cave (Asturias, Northern Spain) (Corchón et al., 2008) has been recovered from a Palaeolithic deposit in Europe.

Within these archaeological sites, whale barnacles have provided indirect evidence for the exploitation of whales. Humans would have found and processed the cetacean stranded on a beach and taken back certain parts, such as meat, blubber, and skin with attached barnacles to the site (Smith and Kinahan, 1984; Jerardino and Parkington, 1993; Kandel and Conard, 2003). Bones and teeth are also used in the manufacture of artifacts, such as points (Petillon, 2008) and pendants (Álvarez-Fernández, 2011). 
Table 1

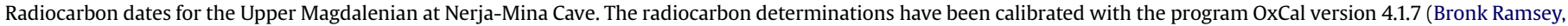
2009) against the IntCal09 calibration curve (Reimer et al., 2009).

\begin{tabular}{|c|c|c|c|c|c|c|}
\hline Layer & Sample & Method & Labor cod. & Dates ${ }^{14} \mathrm{C} B P$ & Dates cal. BP (95\%) & Reference \\
\hline NM 16 (hearth) & Charcoal & Conv. & UGRA-98 & $12,270 \pm 220$ & $15,110-13,750$ & (Jordá and Aura, 2008) \\
\hline NM 16 (hearth) & Charcoal & Conv. & UGRA-147 & $12,060 \pm 150$ & $14,540-13,480$ & (Jordá and Aura, 2008) \\
\hline NM 16 & Charcoal (Quercus sp.) & AMS & BETA-313434 & $11,970 \pm 50$ & $13,980-13,700$ & This paper \\
\hline NM 16 & Burnt pine kernel husk & AMS & SANU-21923 & $12,236 \pm 64$ & $14,800-13,860$ & This paper \\
\hline NM 16 & Pinus pinea, kernel husk & AMS & SANU-21924 & $12,231 \pm 55$ & $14,530-13,880$ & This paper \\
\hline NM 16.1 (hearth) & Charcoal & Conv. & UBAR-97 & $11,850 \pm 190$ & $14,130-13,300$ & (Jordá and Aura, 2008) \\
\hline
\end{tabular}

This study analyzed over a hundred barnacle plates from the Upper Magdalenian layers of Nerja Cave (Mina Chamber). They belong to two whale barnacle species (Tubicinella major and Cetopirus complanatus) identified for the first time in a prehistoric site.

\section{Location and stratigraphy of Nerja Cave}

Nerja ( $36^{\circ} 45^{\prime} 48^{\prime \prime} \mathrm{N}, 3^{\circ} 50^{\prime} 37,36^{\prime \prime} \mathrm{W}$, DATUM ED50) is an important cave located on the SW slope of the Almijara Sierra, at $158 \mathrm{~m}$ altitude above the Mediterranean Sea and $935 \mathrm{~m}$ from the current coastline (Fig. 1A).

Three different chambers with archaeological deposits close to the palaeo-entrance have been documented in Nerja Cave: Torca, Mina and Vestíbulo chambers. These deposits formed in the cave in the final stages of the Late Pleistocene and Holocene, covering the end of MIS 3 to the first half of MIS 1 with a chronological span between 29,600 and 3940 cal BP, according to the information provided by radiocarbon dating. Sedimentation began in the interstadial complex GI 4 immediately after Heinrich event 3, and ended in the Sub Atlantic chronozone. Six episodes of occupation are well defined (Gravettian, Solutrean, Magdalenian, Epipaleolithic, Neolithic and Chalcolithic), and the Mesolithic is more poorly-delimited. All are separated by hiatuses of varying duration (Jordá and Aura, 2008).

\section{Excavations in Mina Chamber: the Magdalenian layers}

Between 1979 and 1986 Professor F. Jordá conducted an excavation in Mina Chamber. He documented 19 layers with abundant archaeological remains ranging from the Gravettian to the Chalcolithic Age (Aura et al., 2001, 2002, 2010; Jordá and Aura, 2008, 2009; Jordá et al., 2011).

The Mina Chamber was the central dwelling space for the Late Glacial human occupations at Nerja Cave (14,920-11,360 cal BP). Its large size and orientation favoured repeated occupations, which were affected by a series of erosional events. The whale barnacles presented here were recovered in layers NM 16, NM 15 and NM 14 (from bottom to top) (Fig. 1B). These layers are ascribed to the Mediterranean Upper Magdalenian chrono-cultural period. The chronology of layer NM 16 extends from 14,920 to 13,570 cal BP (Jordá and Aura, 2009) and corresponds to Greenland Interstadial 1. Two new AMS dates were obtained from a Pinus pinea pinecone bract in Layer NM $16(12,236 \pm 64 \mathrm{BP}$ and $12,231 \pm 55 \mathrm{BP})$ provided the calibrated date 14,680-14,010 cal BP (Table 1 ). The upper layers (NM 15 and NM 14) reflect a number of occupations in the form of sediment lenses partly eroded by Layer NM 13, when fluvial activity caused lateral discontinuities. Layer NM 15, one of the coldest events of the sequence, coincides with Greenland Interstadial 1b. At this time the shoreline was $75-70 \mathrm{~m}$ below the current sea level and the distance from the cave to the sea was $4 \mathrm{~km}$ (Jordá et al., 2011). The sea surface temperature (SST) was $12^{\circ}-15.5^{\circ} \mathrm{C}$.

The levels were excavated in $1 \mathrm{~m}^{2}$ squares, named in binary form with a capital letter and a number. Excavations followed the natural stratigraphic units, but thicker levels (from 2 to $5 \mathrm{~cm}$ ) were dug in thin de facto spits to maintain control. The archaeological materials were recovered from the sediment with a triple mesh with screen sizes of 8,5 , and $1 \mathrm{~mm}$. The different remains were cleaned with fresh water, dried, packed in plastic bags and transported to the laboratory of the Department of Prehistory, University of Salamanca, where they were sorted and classified.

\section{Archaeological record of the Magdalenian layers at Nerja Cave (Mina Chamber)}

Layers 16, 15 and 14 of Mina Chamber contain thousands plant, invertebrate and vertebrate remains alongside abundant lithic and bone artefacts. It is apparent that Magdalenian human groups exploited all the resources to be found in the environment surrounding the cave (Aura et al., 2002, 2009).

Preliminary palaeofaunal analyses indicate a great diversity in fauna. Although rabbits dominate the assemblage, other animals, (e.g. ibex, red deer, wild boards), and marine species (molluscs, sea urchins, mammals, fish and birds) are also present (Eastham, 1986; Jiménez, 1986; Jordá, 1986; Villalba et al., 2007). Charcoal analysis has revealed the effects of the Late Glacial increase in temperature, with the presence of Pinus pinea and other thermophilous taxa, contrasting with LGM contexts of the cave where the cryophilous pines (P. nigra-sylvestris) were abundant (Aura et al., 2010).

Lithic and bone industry is characteristic of the Mediterranean Upper Magdalenian. Backed and truncated bladelets and scrapers reach $60 \%$ of the retouched lithic assemblage, and bone and antler were used make to elaborate points, needles and harpoons. A large number of pendants were made primarily of Cyclope pellucida shells (Aura et al., 2009).

\section{Whale barnacle plates in the Magdalenian layers at Nerja Cave (Mina Chamber)}

\subsection{Identification, quantification and MNI}

A total of 167 whale barnacle (Cirripedia, Balanomorpha, Coronulidae) remains are reported from Nerja-Mina. They belong to two species, Tubicinella major Lamarck, 1802 and Cetopirus complanatus (Mörch, 1853) (Fig. 2; Table 2).

\section{Table 2}

Whale barnacle distribution (NISP: Number of Identified Specimens) in the Layers NM 16, NM 15 and NM 14 at Nerja Cave (see Fig. 3A and B).

\begin{tabular}{|c|c|c|c|c|c|}
\hline & NM 16 & NM 15 & NM 14 & NM 13 & Total \\
\hline \multicolumn{6}{|l|}{ Tubicinella major } \\
\hline Wall and fragments of wall & 6 & 0 & 1 & 0 & 7 \\
\hline Carina $(\mathrm{C})$ and fragments of $\mathrm{C}$ & 9 & 8 & 2 & 1 & 20 \\
\hline Rostrum (R) and fragments of $R$ & 14 & 9 & 2 & 1 & 26 \\
\hline $\begin{array}{l}\text { Lateral }(\mathrm{L}) \text { or Carinolateral }(\mathrm{CL}) \\
\text { and fragments of } \mathrm{L} \text { or } \mathrm{CL}\end{array}$ & 45 & 28 & 17 & 5 & 95 \\
\hline Fragments of indeterminate plate & 8 & 1 & 2 & 0 & 11 \\
\hline Total & 82 & 46 & 24 & 7 & 159 \\
\hline \multicolumn{6}{|l|}{ Cetopirus complanatus } \\
\hline Wall and fragments of wall & 2 & 0 & 1 & 0 & 3 \\
\hline Carina $(\mathrm{C})$ and fragments of $\mathrm{C}$ & 0 & 0 & 1 & 0 & 1 \\
\hline Fragments of indeterminate plate & 2 & 1 & 0 & 1 & 4 \\
\hline Total & 4 & 1 & 2 & 1 & 8 \\
\hline
\end{tabular}



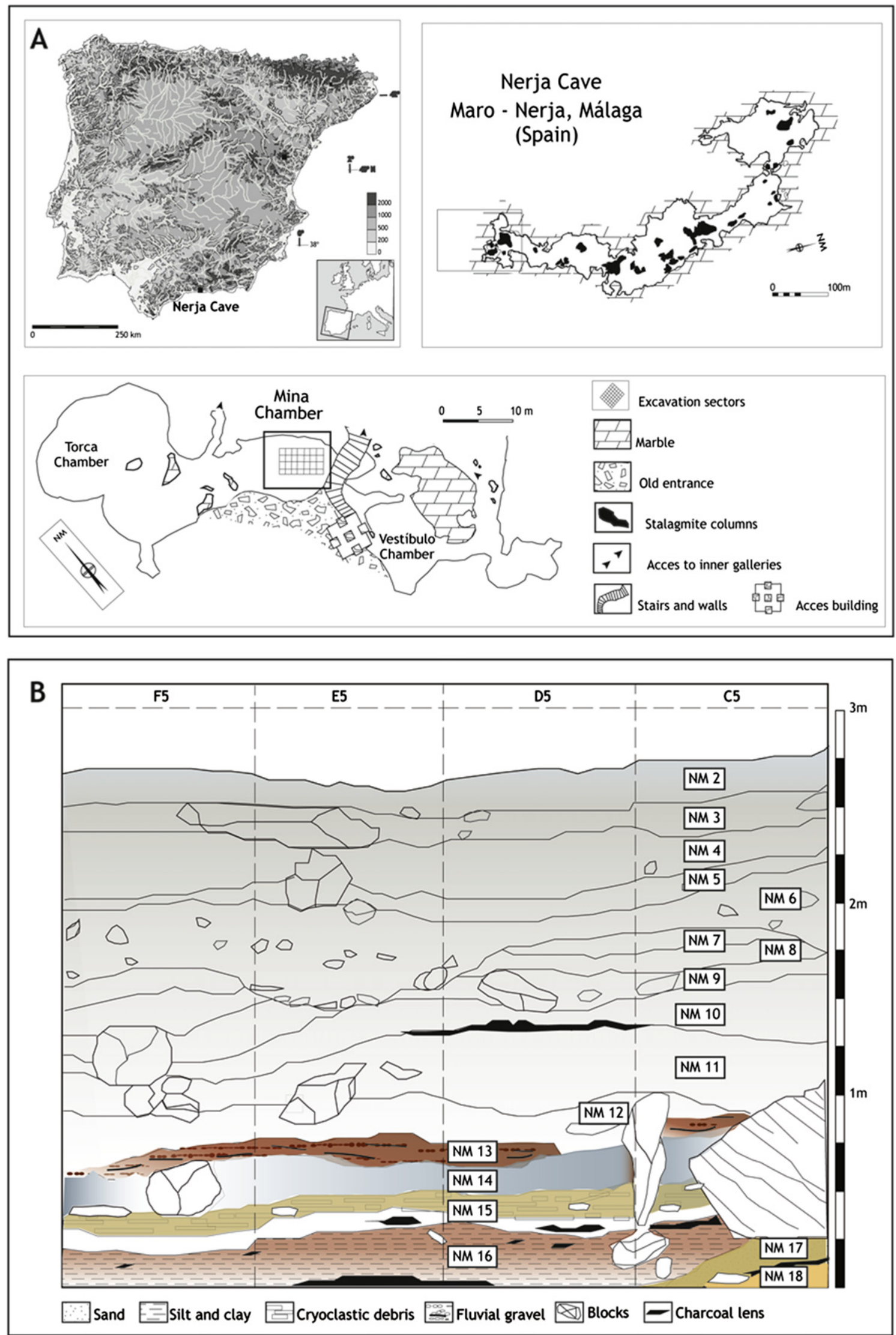

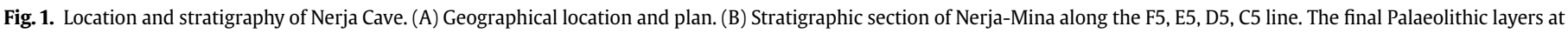

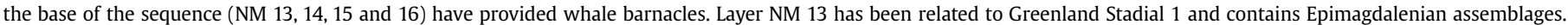
Layers NM 14, 15 and 16 have been linked to Greenland Interestadial 1 and Upper Magdalenian chrono-cultural occupations. Layer NM 17 corresponds to LGM occupations. 


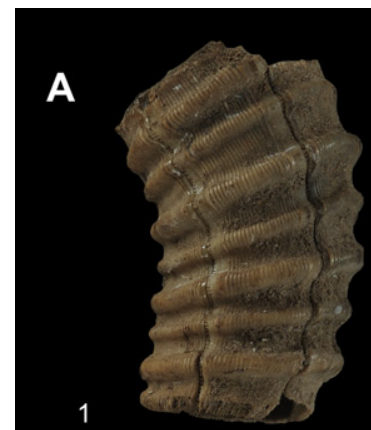

2

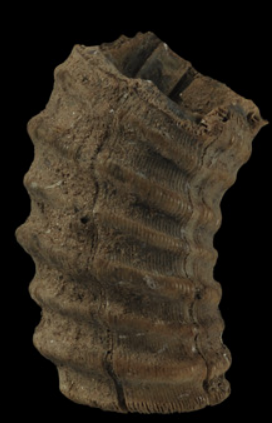

3

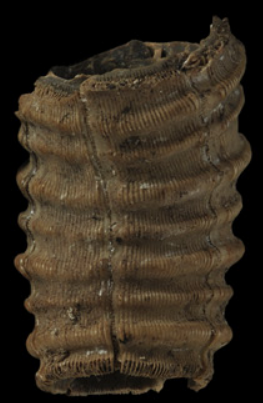

B
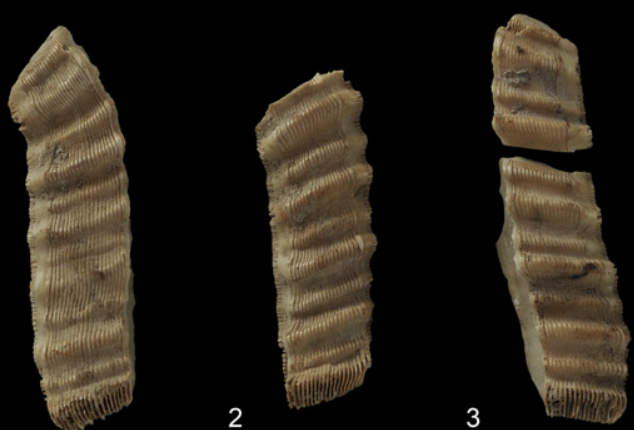

4
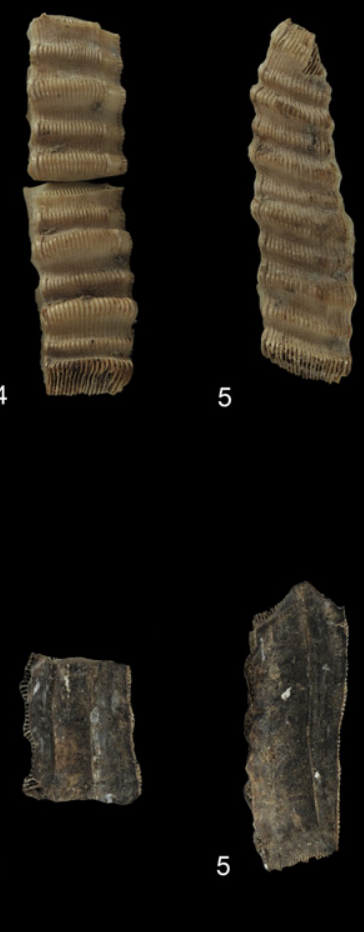

3

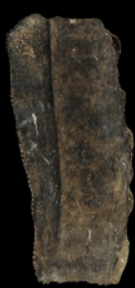

1

2
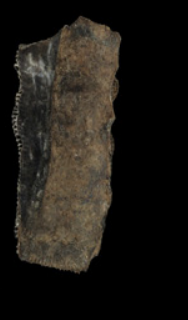

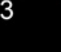

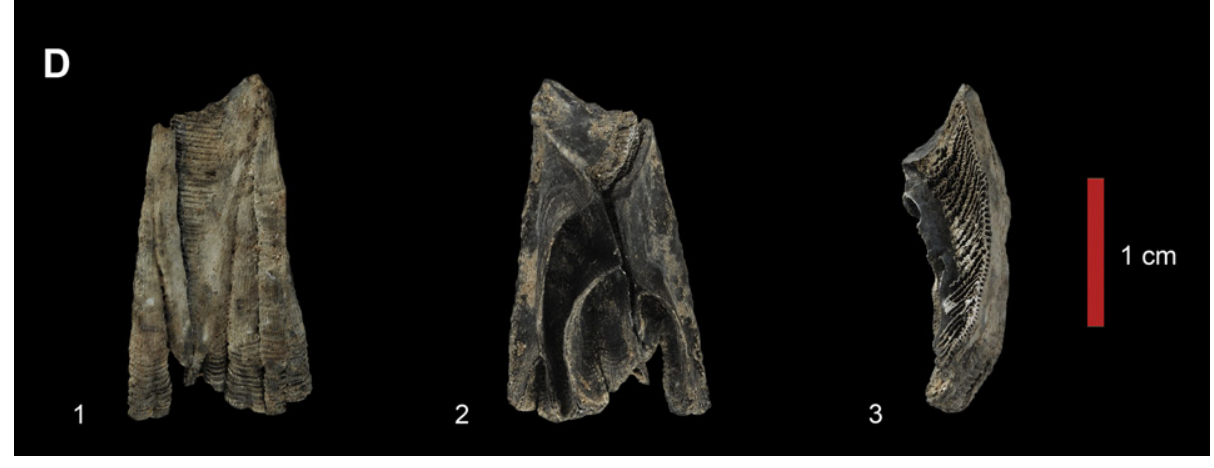

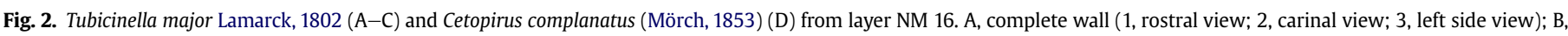

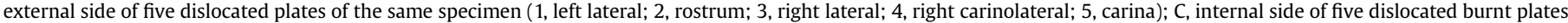
of the same specimen (1, carina; 2, left carinolateral; 3, left lateral; 4, rostrum; 5 , right lateral); D, fragment of wall (1, radial view; 2, exterior view; 3, interior view). 
Tubicinella major - 159 fragments, some burnt, were recorded in the different layers (one complete well-preserved shell without opercular valves; six incomplete walls refitted from complete plates and fragments of plates; numerous complete and fragmented isolated wall plates).

An MNI of 13 is based on complete and incomplete rostra plates with well-preserved basal margins. The complete specimen (16.2 $\mathrm{mm}$ in diameter at its upper end and $24.8 \mathrm{~mm}$ in height) has an elongated, sub-cylindrical shell, with the upper end rather wider than the lower, surrounded by several very prominent, strong, blunt ridges that are irregularly spaced. The surface is finely striated longitudinally. The six compartments are of nearly equal sizes and shapes. The radii are narrow. The membranous basis and the operculum (four nearly equal-sized, similar valves) are absent (in accordance with the descriptions of Darwin (1854)).

Cetopirus complanatus - Only 8 burnt fragments $(\mathrm{MNI}=3)$ have been recovered. Externally, these are characterised by their subdivided parietal ribs. Internally the cutting edges at the base have a treelike pattern and the radii are thick, with their laminate edge covering almost the whole section area of the compartment (in accordance with the description of Pilsbry (1916) and Pastorino and Griffin (1996)).

\subsection{Taphonomy}

Fragments of T. major barnacles, both fresh and burnt, display a delicate micro-structure with walls filled with allochthonous sediments compatible with the regional metapelites (metamorphosed rocks) under an Environmental Scanning Electron Microscope (ESEM). Such sediments are present in the cave sediments and beaches near Maro today. The curves of the cathodoluminescence spectra indicate that the barnacles were buried in wet conditions for a prolonged duration.

Microscopic features diagnostic of human intervention (e.g. cut marks made during the extraction of the animals from the skin of the whale, in the apical part of the wall) are absent. In spite of opercular plates (scuta and terga) not being documented in the sediment sieving, it is not ruled out that humans consumed these animals, breaking the plates and extracting the soft part of the barnacle.

The fragmentation of the barnacles, probably by trampling, is high. Around $22 \%$ of the T. major $(n=34)$ and of the $C$. complanatus $(n=3)$ present evidence of heating, possibly because of the proximity of the two hearths documented in Layer NM 16 in which over $60 \%$ of the burnt plates were located.

A
\begin{tabular}{|c|c|c|c|c|c|c|c|c|}
\hline & G & F & E & D & C & B & A & $\Sigma$ \\
\hline \hline 6 & & & 5 & 18 & $3(+4)$ & & & 30 \\
\hline 5 & & $23(+3)$ & 5 & 15 & & 2 & 9 & 57 \\
\hline 4 & 3 & 21 & 8 & 15 & 3 & $7(+1)$ & & 58 \\
\hline 3 & 2 & 10 & 3 & 3 & & & & 18 \\
\hline 2 & 4 & & & & & & & 4 \\
\hline NR: & 9 & 57 & 21 & 51 & 10 & 10 & 9 & 167 \\
\hline
\end{tabular}

\subsection{Stratigraphic distribution}

The spatial distribution of whale barnacle fragments in the Magdalenian layers is shown in Fig. 3. 53.3\% of the fragments were found within level 16 , and $80.8 \%$ were found within levels 16 and 15. C. complanatus are present in Layers NM 13,14 and 16.

In view of the distribution, all the whale barnacles resulted from a single episode of activity in level 16 . The plates in higher layers, particularly NM 15, were moved from NM 16 through anthropogenic activity, such as trampling. This is supported by the fact that two fragments, one from NM 16 and one from NM 15, have been refitted.

\section{Other marine remains in the Magdalenian layers at Nerja Cave (Mina Chamber)}

Over 40 vertebrate and invertebrate marine species have been found in the Upper Magdalenian levels. The only marine mammal bones documented at Nerja Cave belong to Delphinus delphis (short-beaked common dolphin). Seventeen remains (3 mandibles, 13 teeth and 2 vertebrae) were recovered from NM 16, and one vertebra fragment was found in NM 14 (Fig. 4). Bones and teeth of dolphin are human-modified (burning, butchery marks, fragmented), and it is likely that animals found stranded on the beach were deboned and taken back to the cave where they processed further and consumed (Aura et al., 2002, 2009).

The most abundant remains within the Magdalenian layers are marine mollusc shells, which are dominated by the bivalves Ruditapes decussatus and Mytilus edulis ( $>50 \%$ ) (Jordá, 1986). These shells indicate that humans exploited both sandy and rocky substrates.

Sea birds are also present. Some (e.g. Pinguinus impennis, great auk) are cold-adapted species. They were hunted as food during the autumn and early winter as a food resource, and probably also to obtain feathers for personal decoration (Eastham, 1986).

Eleven families of marine fish were identified. Sparidae and Mugilidae are the most abundant (ca. 75\% of the remains). Mullet was caught on rocky coasts, and sea bream, in estuaries. Other families (e.g. Scombridae) are indicative of spring/summer fishing (Aura et al., 2002).

The sea urchin Paracentrotus lividus was collected as a food resource from rocky substrates (Villalba et al., 2007).

As well, some acorn barnacle plates were found isolated in the sediments. It is possible that they became detached from the external surface of molluscs taken to the site as food.

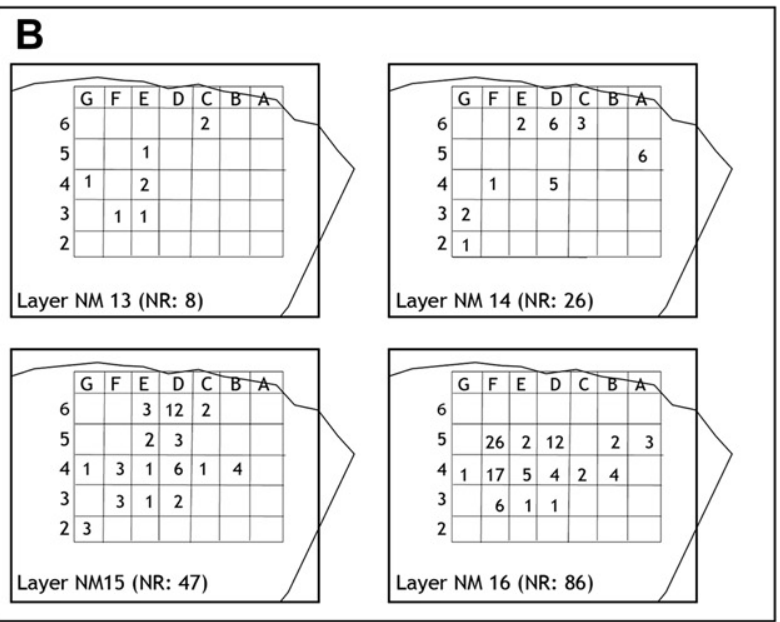

Fig. 3. Whale barnacle distribution (NISP) in the Magdalenian layers from Nerja-Mina. Distribution by square meters (A) and by layers (B). 


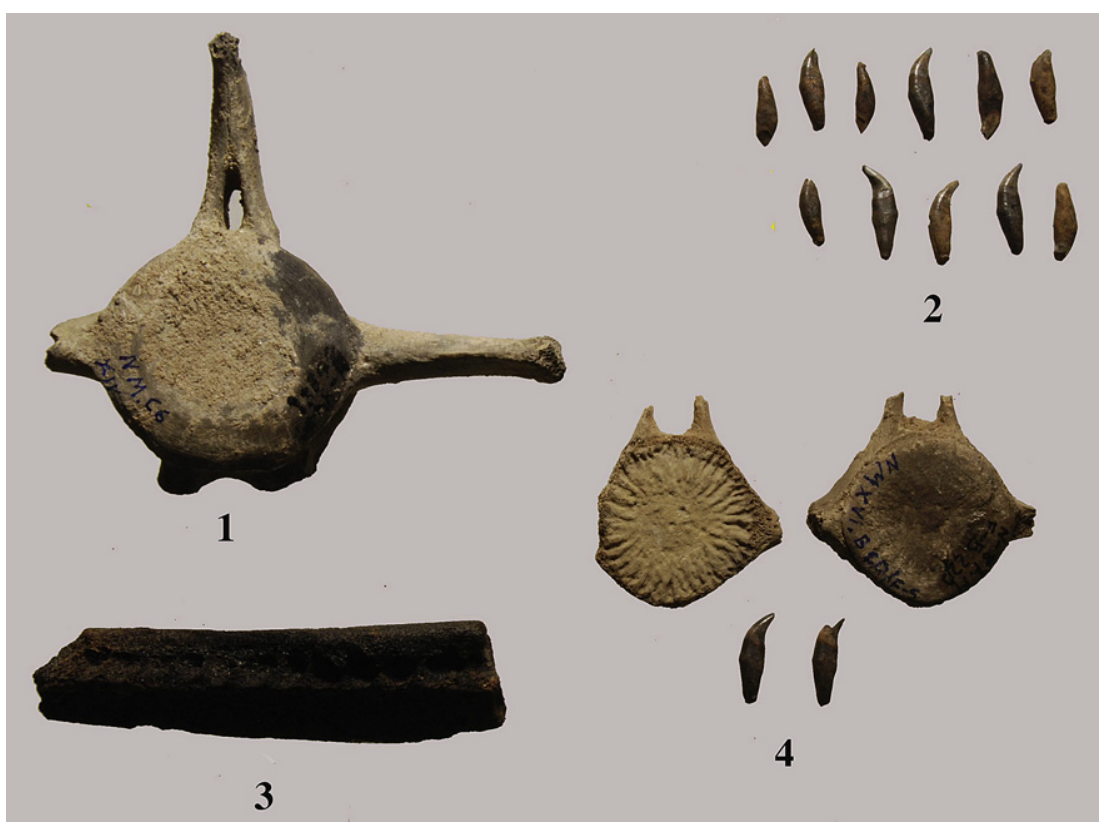

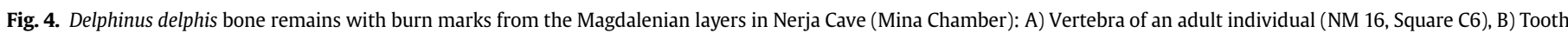
(NM 16.2, Square C6), C) Fragment of a mandible (NM 16.1, Square E5), D) Two vertebrae of a young individual and two teeth (NM 16, Square F5).

\section{Discussion and conclusions}

Three species of right whale species are known (Rosenbaum et al., 2000; Gaines et al., 2005; Kaliszewska et al., 2005), including Eubalaena australis (Desmoulins, 1822), the southern right whale, and Eubalaena glacialis (Müller, 1776), the North Atlantic right whale.

According to Newman and Ross (1976) and Ross and Frick (2007), T. major is found in the Southern Atlantic and Pacific Oceans only on the southern right whale. Ross and Frick (2007) cite only two reports that question the exclusive presence of $T$. major in the Southern Hemisphere. Worm (1655, in Pilsbry, 1916) supplied two characteristic illustrations of tubicinellid found on the head of an unknown whale species stranded on the coast of Syderoe (Faroe Islands). Mitchell and Kozicki (1975) report an unconfirmed record on a stranded bottlenose whale (Hyperoodon ampullatus) in Nova Scotia (Canada).

In contrast, $C$. complanatus uses both species of right whale as a host (E. australis and E. glacialis) and is therefore found in both the Southern Hemisphere and the Northern Hemisphere (Holthuis et al., 1998). Chemnitz (1785, in Scarff, 1986; Holthuis et al., 1998) gives the first description of $C$. complanatus on a right whale in the Northern Hemisphere. In a study of archaeological assemblages at the 10th century city of Tiel (the Netherlands), Holthuis (in Holthuis et al., 1998) concludes that $C$. complanatus was present in the Northern Hemisphere at least until the end of the 19th century. Considering the historical distribution of T. major and C. complanatus and the fact that they co-occur at Nerja, it is likely that these two species had the southern right whale, E. australis, as a host.

At present, in the Southern Hemisphere, E. australis has a circumpolar distribution, ranging from about $20^{\circ}$ to $50^{\circ} \mathrm{S}$. In the North Atlantic E. glacialis extends from about $25^{\circ}$ to $75^{\circ} \mathrm{N}$. These species show regular north-south migrations from higher latitudes in summer to lower latitudes in winter. Today the two species are isolated because they avoid warm tropical waters (Cummings, 1985; Reeves et al., 2002).

However, during the Last Glacial period, the Atlantic Thermohaline Circulation changed because of the expansion of Antarctic sea-ice (Rahmsdorf, 2002). This allowed southern right whales hosting T. major and C. complatatus to migrate towards the equator during the cold Greenland Interstadial 1b (Mcleod et al., 1993). This is not the only explanation, as it is possible that a southern right whale was simply disorientated.

The analysis of the faunal remains in Nerja-Mina (Layers NM 16, NM 15 and NM 14) suggests that Magdalenian foragers were maritime-oriented (Aura et al., 2001) as 67\% of the faunal remains have a marine origin (NM 16: 53.2\%). Fish and mollusc remains represent $71 \%$ of the marine fauna in this period. Marine mammals are not as common (NM 16:0.59\%; NM 14: 0.03\%), but dolphin bones indicate that they were butchered and cooked in the cave (Table 2). Barnacles (at least 13 of T. major and 3 of $C$. complanatus) provide the only evidence for the consumption of whales in Nerja, increasing further the significance of marine foods in the diet.

Table 3

Nerja-Mina: the NISP of the faunal remains in the Magdalenian layers.

\begin{tabular}{lrrrr}
\hline & NM 16 & NM 15 & NM 14 & Total \\
\hline Terrestrial mammals & 918 & 601 & 543 & 2062 \\
Marine mammals & 17 & 0 & 1 & 18 \\
Marine fish & 345 & 774 & 1006 & 2125 \\
Crustaceans (Balanomorpha) & 81 & 37 & 22 & 140 \\
Echinoderms & 204 & 833 & 334 & 1371 \\
Reptilian & 1 & 0 & 54 & 55 \\
Birds & 20 & 16 & 12 & 48 \\
Marine mollusks & 858 & 449 & 376 & 1683 \\
Fluvial mollusks & 2 & 1 & 0 & 3 \\
Terrestrial mollusks & 399 & 214 & 160 & 773 \\
Total & 2845 & 2925 & 2508 & 7918 \\
\hline
\end{tabular}

Whale barnacles indicate that human groups found at least one stranded whale on the coast near the site. Because of the size and weight of whale bones, only skin with blubber, and possibly red meat, was transported to the cave to be consumed or stored. Whale barnacles are buried in the whale's epidermis and can only be detached when the meat and blubber are processed and consumed (Jerardino and Parkington, 1993; Kandel and Conard, 2003). Perhaps as a result of this preparation, a large percentage of the remains are burnt and were found in connection with hearths. 


\section{Acknowledgements}

We wish to thank F. J. Aznar (Universitat de València, Spain), Ph. Clapham (National Marine Mammal Laboratory-Alaska Fisheries Science Center, Seattle, USA), M. Cubas (Sociedad de Ciencias Aranzadi, San Sebastián, Spain), M. Cueto (IIIPC-University of Cantabria, Santander, Spain), M. G. Frick (Caretta Research Project, Savannah, USA), Y. Gruet (Université de Nantes, France), G. Notarbartolo di Sciara (Tethys Research Institute, Milano, Italy) and J. A. Raga (Universitat de València) for thorough-provoking discussions and suggestions and our referees for their careful review of the manuscript. We also thank P. Loubry (Département Histoire de la Terre, Muséum National d'Histoire Naturelle, Paris) for the photos of the barnacles. This work is funded by the NPI of the Spanish Ministry of Economy and Competitiveness (Projects: HAR200803005 and HAR2011-29907-C03-03/HIST).

\section{References}

Álvarez-Fernández, E., 2011. Humans and marine resource interaction reappraised: archaeofauna remains during the Late Pleistocene and Holocene in Cantabrian Spain. Journal of Anthropological Archaeology 30, 327-343.

Aura, J.E., Jordá, J.F., Morales, J.V., Pérez, M., Villalba, M.P., Alcover, J.A., 2009. Economic transitions in finis terra: the western Mediterranean of Iberia, 15-7 ka BP. Before Farming 2009 (2), 1-17.

Aura, J.E., Jordá, J.F., Pérez, M., Badal, E., Morales, J.V., Avezuela, B., Tiffagom, M. Jardón, P., 2010. Treinta años de investigación sobre el Paleolítico superior de Andalucía: la cueva de Nerja (Málaga, España). In: Mangado, J. (Ed.), El Paleolítico Superior Peninsular. Novedades del siglo XXI. SERP, Barcelona, pp. 149-172.

Aura, J.E., Jordá, J.F., Pérez, M., Rodrigo, M.J., 2001. Sobre dunas, playas y calas. Los pescadores prehistóricos de la Cueva de Nerja (Málaga) y su expresión arqueológica en el tránsito Pleistoceno - Holoceno. Archivo de Prehistoria Levantina 24, 9-39.

Aura, J.E., Jordá, J.F., Pérez, M., Rodrigo, M.J., Badal, E., Guillém, P., 2002. The far south: the Pleistocene-Holocene transition in the Nerja Cave (Andalucía, Spain). Quaternary International 93-94, 19-30.

Avery, G., Halkett, D., Orton, J., Steele, T., Tusenius, M., Klein, R., 2008. The Ysterfontein 1 Middle Stone Age rockshelter and the evolution of coastal foraging. South African Archaeological Society Goodwin Series 10, 66-89.

Bronk Ramsey, C., 2009. Bayesian analysis of radiocarbon dates. Radiocarbon 51, 337-360.

Chemnitz, J.H., 1785. Neues systematisches Conchylien-Cabinet. Raspe, Nürnberg pp. $\mathrm{i}-\mathrm{xviii}+372$.

Colonese, A.C., Mannino, M.A., Bar-Yosef Mayer, D.E., Fa, D.A., Finlayson, J.C., Lubell, D., Stiner, M.C., 2011. Marine mollusc exploitation in Mediterranean prehistory: an overview. Quaternary International 239, 86-103.

Corchón, M.S., Mateos, A., Álvarez-Fernández, E., Delclòs, X., Peñalver, E., van der Made, J., 2008. Ressources complémentaires et mobilité dans le Magdalénien Cantabrique. Nouvelles données sur les mammifères marins, les crustacés, les mollusques et les roches organogènes de la Grotte de Las Caldas (Asturies, Espagne). L'Anthropologie 112 (2), 284-327.

Cummings, W.C., 1985. Right whales-Eubalaena glacialis and Eubalaena australis. In: Ridgway, S.H., Harrison, E. (Eds.), Handbook of Marine Mammals. The Sirenians and Baleen Whales, vol. 3. Academic Press, London, pp. 275-304.

Darwin, C., 1854. A Monograph on the Sub-class Cirripedia, With Figures of All Species. In: The Balanidae, (or Sessile Cirripedes); the Verrucidae, Etc.. Royal Society, London, pp. i-viii+684.

Desmoulins, A., 1822. Baleine: in Dictionaire classique d'Histoire naturelle. 2. Rey et Gravier, Paris, pp. 155-160

Eastham, A., 1986. The birds of the Cueva de Nerja. In: Jordá, F.J. (Ed.), La Prehistoria de la Cueva de Nerja. Patronato de la Cueva de Nerja, Málaga, pp. 107-131.

Erlandson, J.M., 2001. The archaeology of aquatic adaptations: paradigms for a new millennium. Journal of Archaeological Research 9, 287-350.

Gaines, C.A., Hare, M.P., Beck, S.E., Rosenbaum, H.C., 2005. Nuclear markers confirm taxonomic status and relationships among highly endangered and closely related right whale species. Proceedings of the Royal Society of London. Series B, Biological Sciences 272, 533-542.

Holthuis, L.B., Smeenk, C., Laarman, F.J., 1998. The find of a whale barnacle, Cetopirus complanatus (Mörch, 1853), in 10th century deposits in the Netherlands. Zoologische Verhandlingen 323, 349-363.

Jerardino, A., 2010. Large shell middens in Lamberts Bay, South Africa: a case of hunter gatherer resource intensification. Journal of Archaeological Science 37, 2291-2302.

Jerardino, A., Marean, C.W., 2010. Shellfish gathering, marine palaeoecology and modern human behavior: perspectives from Cave PP13b, Pinnacle Point, South Africa. Journal of Human Evolution 59, 412-424.

Jerardino, A., Parkington, J., 1993. New evidence for whales on archaeological sites in the south-western Cape. South African Journal of Science 89, 6-7.

Jiménez, E., 1986. Los quelonios de la cueva de Nerja. In: Jordá, F.J. (Ed.), La Prehistoria de la Cueva de Nerja. Patronato de la Cueva de Nerja, Málaga, pp. 133-143.

Jordá, J.F., 1986. La fauna malacológica de la Cueva de Nerja. In: Jordá, F.J. (Ed.), La Prehistoria de la Cueva de Nerja. Patronato de la Cueva de Nerja, Málaga, pp.145-177.
Jordá, J.F., Aura, J.E., 2008. 70 fechas para una cueva. Revisión crítica de 70 dataciones C14 del Pleistoceno superior y Holoceno de la Cueva de Nerja (Málaga, Andalucía, España). In: Espacio, Tiempo y Forma. Serie I. Nueva Época, Prehistoria y Arqueología, vol. 1. 239-256.

Jordá, J.F., Aura, J.E., 2009. El límite Pleistoceno - Holoceno en el yacimiento arqueológico de la Cueva de Nerja (Málaga, España): nuevas aportaciones cronoestratigráficas y paleoclimáticas. Geogaceta 4, 95-98.

Jordá, J.F., Maestro, A., Aura, J.E., Álvarez-Fernández, E., Avezuela, B., Badal, E., Morales, J.V., Pérez, M., Villalba, M.P., 2011. Evolución paleogeográfica, paleoclimática y paleoambiental de la costa meridional de la Península Ibérica durante el Pleistoceno superior. El caso de la Cueva de Nerja (Málaga, Andalucía, España). Boletin de la Real Sociedad Española de Historia Natural 105, 137-147.

Kaliszewska, Z.A. Seger, J. Rowntree, V.J., Barco, S.G, Benegas, R, Best, P.B., Brown, M.W., Brownell Jr., R.L., Carribero, A., Harcourt, R., Knowlton, A.R., Marshall-Tilas, K., Patenaude, N.J., Rivarola, M., Schaeff, C.M., Sironi, M., Smith, W.A., Yamada, T.K., 2005. Population histories of right whales (Cetacea: Eubalaena) inferred from mitochondrial sequence diversities and divergences of their whale lice (Amphipoda: Cyamus). Molecular Ecology 14, 3439-3456.

Kandel, A.W., Conard, N.J., 2003. Scavenging and processing of whale meat and blubber by Later Stone Age people of the Geelbel Dunes, Western Cape Province, South Africa. South African Archaeological Bulletin 58, 91-93.

Lamarck, J.-B.P.A., 1802. Mémoire sur la Tubicinelle. Annales du Muséum National d'Histoire Naturelle 1, 461-464.

Mcleod, S.A., Whitmore, F.C., Barnes, L.G., 1993. Evolutionary relationships and classification. In: The Bowhead Whale, vol. 2. The Society for Marine Mammalogy, Lawrence, Kansas, pp. 45-70.

Marean, C.W., 2010. Pinnacle point cave 13B (Western Cape Province, South Africa) in context: the Cape Floral Kingdom, Shellfish, and modern human origins. Journal of Human Evolution 59, 425-443.

Marean, C.W., Bar-Matthews, M., Bernatchez, J., Fisher, E., Goldberg, P., Herries, A.I.R., Jacobs, Z., Jerardino, A., Karkanas, P., Minichillo, T., Nilssen, P.J., Thompson, E., Watts, I., Willians, H.M., 2007. Early human use of marine resources and pigment in South Africa during the Middle Pleistocene. Nature 499 (18), 905-909.

Mitchell, E., Kozicki, V.M., 1975. Autumn strandings of the northern bottlenose whale (Hyperoodon ampullatus) in the Bay of Fundy, Nova Scotia. Journal of the Fisheries Research Board of Canada 32, 139-154.

Mörch, O.A.L., 1853. Acephala. Annulata. Cirripedia. Echinodermata. Catalogus Conchyliorum Quae Reliquit D. In: Alphonso d'Aguirra et Gadea Comes de Yoldi, (Copenhagen), pp. 1-74.

Müller, O.F., 1776. Zoologica Danicae Prodromus seu Animalium Daniae et Norvegiae indigenarum characters, nomine, et synonyma imprimis popularium. Havniae XXXII, 274

Newman, A.W., Ross, A., 1976. Revision of the balanomorph barnacles; including a catalog of the species. San Diego Society of Natural History, Memoir 9, 1-108.

Pastorino, G., Griffin, M., 1996. An extant whale barnacle (Cirripedia, Coronulidae) from Holocene deposits of Buenos Aires (Argentina). Crustaceana 69, 769-772.

Petillon, J.-M., 2008. First evidence of a whale-bone industry in the Western European Upper Paleolithic: Magdalenian artifacts from Isturitz (PyrénéesAtlantiques, France). Journal of Human Evolution 54, 720-726.

Pilsbry, H.A., 1916. The Sessile Barnacles (Cirripedia) Contained in the Collections of the U. S. National Museum; Including a Monograph of the American Species. Bulletin of the United States National Museum 93, Washington, pp. $i-x i+366$.

Rahmsdorf, R., 2002. Ocean circulation and climate during the past 120,000 years. Nature 419, 207-211.

Reeves, R.R., Steward, B.S., Clapham, P.J., Powell, J.A., 2002. Guide to Marine Mammals of the World. Chanticleer Press, New York.

Reimer, P.J., Baillie, M.G.L., Bard, E., Bayliss, A., Beck, J.W., Blackwell, P.G., Bronk Ramsey, C., Buck, C.E., Burr, G.S., Edwards, R.L., Friedrich, M.P., Grootes, M., Guilderson, T.P., Hajdas, I., Heaton, T.J., Hogg, A.G., Hughen, K.A., Kaiser, K.F., Kromer, B., McCormac, F.G., Manning, S.W., Reimer, R.W., Richards, D.A., Southon, J.R., Talamo, S., Turney, C.S.M., van der Plicht, J., Weyhenmeyer, C.E., 2009. Intcal09 and Marine09 radiocarbon age calibration curves, 0-50,000 years cal BP. Radiocarbon 51, 1111-1150.

Rosenbaum, H., Brownell, J.R., Brown, M.W., Schaeff, C., Portway, V., White, B.N., Malik, S., Pastene, L.A., Patenaude, N.J., Baker, C.S., Goto, M., Best, P.B., Clapham, P.J., Hamilton, P., Moore, M., Payne, R., Rowntree, V., Tynan, C.T., Bannister, J.L., Salle, R.D., 2000. World-wide genetic differentiation of Eubalaena: questioning the number of right whale species. Molecular Ecology 9 (11), 1793-1802.

Ross, A., Frick, M.G., 2007. From Hendrickson (1958) to Monroe \& Limpus (1979) and beyond: an evaluation of the turtle barnacle Tubicinella cheloniae. Marine Turtle Newsletter $118,2-5$.

Scarff, J.E., 1986. Occurrence of the Barnacles Coronula diadema, C. reginae and Cetopirus complanatus (Cirripedia) on right whales. The Scientific Reports of the Whales Research Institute 37, 129-153.

Smith, A., Kinahan, J., 1984. The invisible whale. World Archaeology 16, 89-97.

Steele, T.E., Álvarez-Fernández, E. 2011. Initial investigations into the exploitation of coastal resources in North Africa during the late Pleistocene. In: Bicho, N. (Ed.), Trekking the Shore: Changing Coastlines and the Antiquity of Coastal Settlement. Springer, New York, pp. 383-403.

Villalba, M.P., Jordá, J.F., Aura, E., 2007. Los equínidos del Pleistoceno superior y Holoceno del registro arqueológico de la Cueva de Nerja (Málaga, España). Cuaternario y Geomorfología 21, 133-148.

Worm, O., 1655. Museum Wormianum seu Historia Rerum Rariorum. Tam Naturalium, quam Artificialium, tam Domesticarum, quam Exoticarum, quae Hafniae Danorum in aedibus Authoris Servantur. Ludvig Batavorum, Amstelodami. 